\title{
IMPROVING STUDENTS READING COMPREHENSION BY SURVEY, QUESTION, READ, AND WRITE (SQRW) STRATEGY AT GRADE VIII SMP NEGERI 1 PANYABUNGAN
}

\author{
YASPIAH \\ IAIN Padangsidimpuan
}

\begin{abstract}
Abstrak
Penelitian ini membahas tentang peningkatan pemahaman membaca siswa dengan strategi Survey, Question, Read, and Write (SQRW) di kelas VIII SMP Negeri 1 Panyabungan. Sebagian besar siswa memiliki prestasi membaca yang rendah, siswa tidak memiliki banyak kosakata, siswa tidak memiliki strategi yang baik dalam membaca. Permasalahannya dipengaruhi oleh faktor internal dan eksternal. Permasalahan dalam faktor internal adalah kesulitan siswa dalam mengidentifikasi kalimat topik, mengidentifikasi ide pendukung, mengidentifikasi makna kata yang sulit, mengidentifikasi informasi penting, serta mengidentifikasi kesimpulan. Permasalahan dalam faktor eksternal adalah motivasi, pindah ke kursi lain, berisik, dan meminta izin. Penelitian ini bertujuan untuk mendeskripsikan pencapaian siswa dalam pemahaman membaca dan untuk mengidentifikasi faktor-faktor yang mempengaruhi pemahaman membaca siswa dengan menggunakan strategi survey, question, read, and write (SQRW) di kelas VIII SMP N 1 Panyabungan. Metodologi penelitian yang digunakan dalam penelitian ini adalah penelitian tindakan kelas dengan menerapkan desain Kemmis yang terdiri dari empat langkah sebagai; perencanaan, tindakan, pengamatan, dan refleksi. Untuk memecahkan masalah siswa dalam membaca pemahaman, peneliti menerapkan strategi SQRW. The researcher used two cycles; every cycle consisted of two meetings. Selain itu, peserta penelitian ini adalah kelas VIII (23 siswa) dan ada kolaborasi dengan guru bahasa Inggris. Sementara itu, data berasal dari tes membaca pemahaman, observasi, dan wawancara. Berdasarkan hasil penelitian, menunjukkan peningkatan skor rata-rata siswa. Skor siswa pada siklus 1 adalah 53,69 (26,08\%) dan skor siswa di siklus 2 adalah 75,65 (69,56\%). Dari skor rata-rata siswa dalam siklus 1. Dapat disimpulkan bahwa skor rata-rata pada siklus kedua lebih tinggi dari siklus pertama. Berdasarkan catatan observasi dinyatakan bahwa siswa mendapat peningkatan dan siswa lebih aktif dan tertarik untuk belajar membaca pemahaman. Terkait dengan hasil wawancara, dapat diketahui bahwa pemahaman membaca siswa telah meningkat. Ini menegaskan bahwa dengan menggunakan strategi SQRW meningkatkan pemahaman membaca siswa.
\end{abstract}

Kata Kunci: Pemahaman Membaca, Strategi SQRW, SMP Negeri 1 Panyabungan

\footnotetext{
Abstract

This research was talking about improving students' reading comprehension by Survey, Question, Read, and Write (SQRW) strategy at grade VIII SMP Negeri 1 Panyabungan. Most of students had low achievement in reading comprehension, students did not have many vocabulary, students did not have good strategy in
} 
reading. The problems were influenced by internal and external factors. The problems in internal factors were students' difficulties in identifying topic sentence, identifying supporting idea, identifying meaning of difficult word, identifying important information, and identifying conclusion. The problems in external factors were motivation, move to another chair, noisy, and asking permission. This research purposed to describe the students' achievement in reading comprehension and to identify the factors which influence students' reading comprehension by using survey, question, read, and write (SQRW) strategy at grade VIII SMP N 1 Panyabungan. Research methodology that used in this research was classroom action research by implementing the Kemmis design which consisted of four steps as; planning, acting, observing, and reflecting. To solve the students' problems in reading comprehension, the researcher applied SQRW strategy. The researcher used two cycles; every cycle consisted of two meetings. Moreover, the participants of this research were the class of VIII (23 students) and there was collaboration with an English teacher. Meanwhile, the data was derived from reading comprehension tests, observation, and interview. Based on the research result, showed the improvement mean score of the students. Students' score in cycle 1 was $53.69(26.08 \%)$ and students' score in cycle 2 was $75.65(69.56 \%)$. From the students' mean score in cycle 1 . It can be concluded that the mean score in the second cycle was higher than the first cycle. Based on observation notes stated that the students got improvement and the students were more active and interested in learning reading comprehension. Related to the interview result, it could be known that students' reading comprehension had improved. It asserted that by using SQRW strategy improve students' reading comprehension.

Keywoards: Reading Comprehension, SQRW Strategy, SMP Negeri 1 Panyabungan

\section{BACKGROUND OF THE PROBLEM}

Reading is very important in many aspects in life. Some of important of reading are; activating mind, get a lot of knowledge about many things in the world such as sciences, technology, sport, arts, cultures, religious, and give us pleasure too. Reading is the most important skill for English learners. In reading, the readers can explore new thing, activated their brain, and making the good one in mind. These important are explained in the following paragraph.

Some important of reading above show that people must pay attention to their reading and don't underestimate it. Reading should be mastered by everybody, more over students. Based on the interview, the researcher got the information from one of the teachers of English subject that students at Grade VIII SMP N 1 Panyabungan have problem on reading comprehension. It can be seen based on illustration below: 
The first, when the researcher asked the English teacher of SMP N 1 Panyabungan. She said that the Students reading comprehension is low. ${ }^{1}$ Based on KKM of English subject the passing grade in the examination is 75. But, the data found in of some students at grade VIII of SMP N 1 Panyabungan reveals the average is $70 .{ }^{2}$ So, students reading comprehension does not fulfill the expectation.

The second, in addition the students' also have difficulty in understanding the texts or to get the information from the texts when they read because they are lack of vocabulary and some of difficult words found in the text. Sometime the students get wrong information from the texts and appropriate with the intent or purpose of the author.

The third, students did not have a good strategy in reading. Students must have reading strategy to be easier and better to comprehend the text, because reading strategy is important for students and teacher, and reading strategy is way to reach goal in understanding text.

There are reading strategy that can be used to solve the students' problem in reading comprehension in the classroom, and also could increase the students' ability in reading, such as Skimming, Scanning, SQ3R (Survey, Question, Read, Recite, Review), PQ4R (Preview, Question, Read, Reflect, Recite and Review) and SQRW (Survey, Question, Read, and Write).

Based on strategies above, to solve the problem in reading, the researcher chose SQRW strategy. The reason of the researcher to choose the method is explained in the following paragraph. First, SQRW is to make students easier to survey or preview the title and introductory paragraph of the text, read, answer the questions, identify the important information and summarize the information. Second, the reader can prepare a written record of what they learned, the researcher record will be valuable when students have to participate in a class discussion and when students study for a test. The last, according to Mangrum SQRW can improve their reading efficiency in three ways; it increases their comprehension, crease their recall, building students' reading

${ }^{1}$ Khalijah Lubis, English Teacher at SMP N 1 Panyabungan, Private Interview. (December 22, 2014 at 09.00 a.m).

2Students' school report card at SMP N 1 Panyabungan, Private Document. (December 23, 2014 at 11.30 a.m). 
298 | TAZKIR: Jurnal Penelitian Ilmu-ilmu Sosial dan Keislaman

Vol. 03 No. 2 Desember 2017

comprehension skill and it saves students valuable time by encouraging students to learn as students read. ${ }^{3}$

Based on this case, the researcher was interested in conducting a classroom action research (CAR) through the title "IMPROVING STUDENTS' READING COMPREHENSION BY SURVEY, QUESTION, READ, and WRITE (SQRW) STRATEGY AT GRADE VIII SMP NEGERI 1 PANYABUNGAN".

\section{THE FORMULATION OF THE PROBLEM}

The formulations of the problem are: To what extent does Survey, Question, Read, and Write (SQRW) strategy improve students reading comprehension at Grade VIII SMP Negeri 1 Panyabungan?, and What factors influence students' reading comprehension by using Survey, Question, Read, Write (SQRW) strategy at Grade VIII SMP Negeri 1 Panyabungan?

\section{THEORETICAL DESCRIPTION}

\section{Reading Comprehension}

a. Definition of Reading Comprehension

1) Reading

Reading is an interactive process between the reader and the text. According to David Nunan stated that, Reading is a fluent process of readers combining information from a text and their own background knowledge to build meaning. The goal of reading is comprehension. ${ }^{4}$ Reading is a complex process, it involves much more that adding word meaning together. Reading involves not only understanding ideas, but also recognizing the relationship and structures among ideas. ${ }^{5}$

It can be concluded that, reading is the interactive process that happens in human minds to reconstruct the meaning or to get the information for what they have read.

\footnotetext{
${ }^{3}$ Stephen S. Strichart and Charles T. Mangrum, Teaching Learning Strategies-and Study Skills to Students with Learning Disabilities, Attention Deficit Disorders or Special Needs//. (Browsed at April 18, 2015. Time 14.00 p.m).

${ }^{4}$ David Nunan. Practical English Language Teaching (New York: Mc Grow Hill, 2003) p. 68.

${ }^{5}$ Kathlen T. Mc. Whorter. Efficient and Flexible Reading (Harper Collins Publisher, 1992) p.165.
} 
According to Harris, reading is meaningful interpretation of written or printed verbal symbols. ${ }^{6}$ It can apply also to the interpretation of mathematical symbols, musical notation, codes, and other symbolic systems. Next, reading is a process involving meaning is self-evident, but it can hardly be overemphasized that meaningful response is the very heart of the reading process. ${ }^{7}$ It can and should embrace all types of thinking, evaluating, judging, imagining, reasoning, and problem solving.

From all of explanation above researcher concluded that reading is an activity the reader to get information from text or reading is a process communication from the writer to the reader for understanding what means of writer.

2) Comprehension

Comprehension is the ability to understand the meaning from written or spoken language. Jack C. Richards said that comprehension is the primary purpose for reading (though this is sometimes overlooked when students are asked to read overly difficult text), raising students awareness of main ideas in a text and exploring the organization of a text are essential for good comprehension. ${ }^{8}$

Next, Comprehension is activities are require students to demonstrate an understanding of the material through some type of manipulation or alternation of the material before answering a question. The comprehension or understanding may be evidenced by oral, written, pictorial, or concrete presentation. ${ }^{9}$

Based on the explanation above, the researcher concludes that comprehension is a process in which the reader may construct meaning by interacting with the text.

3) Reading Comprehension 1969), p. 3.

${ }^{6}$ Albert J. Harris, How to Increase Reading Ability (New York: David Mckay Company,

${ }^{7}$ Ibid., p.3-4.

${ }^{8}$ Jack C. Richards. Methodology in Language Teaching (New York: Cambridge University Press, 2002), p. 277.

${ }^{9}$ Donald C. Orlich, Teaching Strategies A Guide to Better Instruction (D. C. Heath and Company:Texington Massachusets Toronto), p. 87. 
Reading comprehension is a complex skill includes understanding the text and the component inside. According to Goodman in Otto states "reading comprehension is an interaction between thought and language and bases evaluation of success in comprehension on the extent to which the readers' reconstructed message agrees with the writers' intended message" ${ }^{10}$

Next, Reading comprehension is the understanding, evaluating, and utilizing an ideas gained through and interaction between reader and author. ${ }^{11}$ Here, the reading comprehension involves mental operations applied by the reader.

Last, Roebl states that reading comprehension is an ability to understand what the readers read where words have context and texts have meaning. ${ }^{12}$ The words or text that relate to the context, the reader interprets it firstly to get the factual interpretation or in reading. The readers' background knowledge also helps the reader to get the comprehension in reading.

Based on the explanation above the researcher can be concluded that reading comprehension is a constructive process the visual information and corrects it with information in the text. Reading comprehension text must have interacting between the reader and the writer by having the same interpretation upon the text.

b. Characteristic of Reading

A good way to understand reading is to consider what is required for fluent reading and characteristic of reading. According to Douglas Brown that the characteristic of reading are:

1) Identify your purpose of reading text.

2) Apply spelling rules and convention for bottom up decoding.

3) Use lexical analysis (prefixes, roots, suffixes) to determine meaning.

4) Guess at meaning (of words, idiom, etc) when you are not certain.

10 Wayne Otto, et. al., How to Teaching Reading (Philippines: Addison-Wesley Publishing Company, 1979), p. 151.

${ }^{11} \mathrm{Nil}$ B. Smith and H. Alan Robinson, Reading Instruction for Today's Children (Englewoo Cliffs: 1980), p. 205.

${ }^{12}$ K. M. Roebl, Developing Reading Comprehension Skills in EFL University Level Students (St. John's University: Taiwane, 2003), p. 177. 
5) Skim the text for the gist and for main ideas.

6) Scan the text for specific information (name, date, keyword).

7) Use silent reading techniques for rapid processing.

8) Use marginal notes, outlines, chart or semantic maps for understanding and retaining information.

9) Distinguish between literal and implied meanings.

10) Capitalize on discourse markers to process relationship. ${ }^{13}$

Based on explanation above, many characteristic in teaching reading comprehension, but the purpose of the experts is same. Therefore, the teacher should know the characteristic in teaching reading.

c. Types of Reading

According to Albert J. Harris there are three types of reading related to its purpose; those are Developmental, functional, and recreational. ${ }^{14}$

1) Developmental Reading

a) Skill in the mechanics of reading

(1) Development of a large sight vocabulary.

(2) Development of skill in identifying unfamiliar words.

(3) Development of good eye-movement habits.

(4) Development of proper habits of posture, holding books, and so on.

(5) Development of speed and fluency in silent reading.

(6) Development of oral reading skills; phrasing, expression, pitch, volume, enunciation.

2) Functional Reading

a) Ability to locate needed reading material

(1) Use of index.

(2) Use of table of contents.

(3) Use of dictionary.

(4) Use of encyclopedia.

(5) Use of library card files.

(6) Use of other bibliographic aids.

${ }^{13} \mathrm{H}$. Douglas Brown, Language Assessment Principles and Classroom Practices (United Stated of America: Longman, 2004), p. 188.

${ }^{14}$ Albert J. Harris, How to Increase Reading Ability, p. 9-10. 
(7) Use of skimming in search for information.

b) Ability to comprehend informational material

(1) Application of general comprehension skill listed under A, 2 above.

(2) Development of specific skill needed b special subject matter, e.g., reading of arithmetic problems, reading of maps, charts, and graphs.

c) Ability to select the material needed

d) Ability to organize what is read

(1) Ability to summarize.

(2) Ability to outline.

3) Recreational Reading

a) Development of interest in reading

(1) Enjoyment of reading as a voluntary leisure-time activity.

(2) Skill in selecting appropriate reading matter for oneself.

(3) Satisfaction of present interest and tastes through reading.

b) Improvement and refinement of reading interest

(1) Development of more varied reading interests.

(2) Development of more mature reading interests.

(3) Achievement of personal development through reading.

c) Refinement of literary judgment and taste

(1) Establishment of differential criteria for fiction and nonfiction, prose and poetry, and drama.

(2) Development of appreciation for style and beauty of language.

(3) Learning to seek for deeper symbolic messages.

Based on the explanation above, there are three types of reading, they are developmental reading, functional and recreational reading.

\section{SQRW (Survey, Question, Read, and Write)}

a. Definition of SQRW Strategy

SQRW is a four-step strategy for reading and taking notes from chapters in a textbook. Each letter stands for one step in the strategy. Using SQRW will help you to understand what you read and to prepare a written record of what you learned. The written record will be valuable when you have to participate in a class discussion and again when you study for a test. It is an effective reading process, 
related to some techniques that usually help the readers not only to enjoy their reading but also to read and remember the main point. ${ }^{15}$

SQRW, it might sound sort of complex but its actually quite simple and straight forward. SQRW is a four-step strategy for reading and taking notes from chapters in a textbook that will help you better prepare for exams, better prepare for class discussion, improve your reading comprehension and help you learn better using textbooks. ${ }^{16}$

From explanation above it can be concluded that, by using SQRW strategy students can active in class discussion and there is an interaction between a teacher and the students and can make teaching and learning process more active.

b. Steps of SQRW strategy

SRQRW strategy stand for survey, question, read, and write.

1) Survey

Become familiar with the overall content and organization of the material you already learned this technique and know it as pre-reading. Get an idea of what the chapter is about by the reviewing the highlights: ${ }^{17}$

a) Read the title

b) Read introduction

c) Read Heading

d) Read Summary or conclusion

2) Question

This technique will help the reader focus precisely on what is to be found in that section and will also help to bring to the reader's mind the information her or she. Already knows about the topic. Moreover, the question that will be used in this step is who, what, where, when, why or how to change heading into question. 16.00 p.m).

15 Retrieved from http//www.sqrwreadingstrategy.com//. (Browsed at April 15, 2015. Time

${ }^{16}$ Stephen S. Strichart and Charles T. Mangrum, Teaching Learning Strategies-and Study Skills to Students with Learning Disabilities, Attention Deficit Disorders or Special Needs//. (Browsed at April 18, 2015. Time 14.00 p.m).

${ }^{17}$ Ibid. 
3) Read

The reader is to focus only on the main topic and the important supporting details that are needed to answer their question. Because the reader is seeking the answer to a specific question through this reading, she or he is actively involved in the perusal of the section and is not just passively moving the eyes across down the page.

4) Write

After you've written down each question as well as the answer to each question review each question again to make sure you have completely answered the question. The main point in this step is to remember again what the information that has been learnt with asking and answering the question.

Based on the explanation above, by doing all of the step in SQRW can encourage students to read and feel confident about their ability to understand written text. SQRW is one of the good strategy can improve students' reading comprehension.

c. Procedure of SQRW Strategy

The following are the procedure of SQRW strategy:

1) The student glances quickly through the selection looking at key words and headings in order to get a general idea of the important concept covered by the selection.

2) To turn first, heading into a question.

3) Involves reading the first section in order to answer the question.

4) The reader attempts to reconstruct the answer the question.

5) The reader looks through the notes that have been made, nothing again the key points and the supporting details it.

Based on the explanation above, there are some procedure in teaching reading comprehension by using SQRW strategy in the classroom that make the teacher and the students know what the procedure in SQRW strategy.

\section{RESEARCH METHODOLOGY}

This research has been conducted at SMP Negeri 1 Panyabungan. This school is located at Jln. Bhakti Abri Panyabungan. This school is far from the 
country and it located in the west of Panyabungan. This research has been started from June 2015 until December 2015. The design of this research has been used Classroom Action Research. Classroom action research is a research that can doing in the classroom. It have an important role to improve students' ability and the learning quality. According to L.R Gay and Peter Airasian said that, classroom action research is a type of practitioner's practice; action implies doing or changing something. ${ }^{18}$ Next, Anne Burns said that, classroom action research is part of a board movement that has been going on in education generally for some time, it involves taking a self-reflective, critical, and systematic, approach to exploring your own teaching contexts. ${ }^{19}$

It can be means that classroom action research is the research doing in the classroom to improve students' ability and the learning quality. According to Geoffrey, action research is any systematic inquiry conducted by teacher researchers, principles, school counselors, or other stockholders in the teaching learning environment to gather information about the ways that their particular schools operated, how they thought, and how well their students learnt. ${ }^{20}$ Next, Rohiati said that classroom action research is a research which is combined the procedure in substantive action, be inquiry discipline, or someone's effort to understand what was happening while include in the improving and changing. ${ }^{21}$

Based on the instrument of collecting data, the researcher chose three instrument of collecting data; test, observation, and interview as describe as follow paragraph:

1. Test

Test was orally done for every student at the same time of the activities of the learning through the first cycle and second cycle. Test taker was researcher herself. She to the reading assessment criteria rubric as references in the process of learning to get students' score. Test is some question to get information that pointed understanding vocabulary. ${ }^{22}$

\footnotetext{
18 L.R. Gay and Peter Airasian, Educational Research: Competencies for Analysis and Application (New Jersey: Prentice Hall, 2000), p. 593.

${ }^{19}$ Anne Burns, Doing Action Research in English Language Teaching (New York: Routledge, 2010), p. 2.

${ }^{20}$ Geoffrey E. Mills, Action Research a guide for the Teacher Researcher (New Jersey: Prentice Hall, 2000), p. 6.

${ }^{21}$ Rochiati Wiratmadja, Metode Penelitian Tindakan Kelas (Bandung: Rosda, 2005), p. 11.

${ }^{22}$ L.R Gay\& Peter Airasian, Educational Research: Competencies for Analysis and Aplication., p. 219.
} 
Suharsimi Arikunto stated that: "Test is the instrument which the instrument is arranged with especially because the test is used the measure of something important and certain" ${ }^{23}$

Reading test is to get data from the students' achievement in reading comprehension. In the first cycle, the researcher taught reading comprehension by using SQRW strategy. The researcher gave some narrative texts and explained about how to identify topic sentence, supporting idea, meaning of difficult word, important information, and conclusion by using SQRW strategy. The researcher gave the time to the students to read the narrative text. Then, the researcher gave first test consists of 20 questions (every question consist of indicator of reading test) in multiple choices form.

2. Observation

Observation is used to collect data about students' activity in teaching and learning process and the implementation of collaborative learning method. However, the researcher used observation notes because it is a simple form and the data are not counted but using note to describe what happened in the classroom. The researcher observed students' activities and teachers' activity during the teaching-learning process and the factors which influence the teaching-learning process.

3. Interview

According to L. R Gay and Peter Airasian, interview is purposeful interaction, usually between two people, focused on one person trying to get information from the other person. ${ }^{24}$ Interview permit the researcher to obtain important data that cannot be obtained from observation. The researcher used the interview to know the condition of the students and also to know the students' problems in reading comprehension by using SQRW strategy in the classroom. To know the means' of students score for each cycle, the researcher will apply the following formula:

$$
X=\frac{\sum x}{N} \times 100 \%
$$

The percentage of the students' achievement in reading through SQRW strategy is calculated by applying the following formula:

\footnotetext{
${ }^{23}$ Suharsimi Arikunto, Menajemen Penelitian (Jakarta: PT. Rineka Cipta, 2003), p. 223.

${ }^{24}$ L. R Gay and Peter Airasian, Educational Research: Competencies for Analysis and Aplication.
} p. 219. 


$$
P=\frac{R}{T} \mathrm{X} 100 \%
$$

\section{RESEARCH RESULT}

\section{Students' Achievement}

Students' achievement in reading comprehension by using SQRW strategy at grade VIII SMP Negeri 1 Panyabungan was described in this research as one of the purpose. The researcher found the improvement of students' mean scores and percentage in reading comprehension by using SQRW strategy based on first cycle and second cycle.

Based on the related findings of this research in chapter II, the students' achievements were: the first, Rizka Ummul Khaira, conducted a research which entitles "The Use of SQRW Strategy increasing students' ability in Narrative text at MA Darel Hikmah Pekanbaru". She tried to find out whether there is significant effect use of SQRW. In Pre- Test the ability of students in comprehending text is low. The mean score was 54.03. After that, with Using SQRW strategy the students; reading comprehension can increase the average of students was $19.2 \%$ or score 62

The second, Arisan Jaya has researched about "Improving Students' Reading Comprehension by Using P2R (Preview, Read, Review) At Grade VIII Pondok Pesantren Al-Mukhlishin Lumut". She said that students' reading comprehension has improved well by using P2R strategy. It based on the reading comprehension mean score in which was in cycle1 were 40.80 $(51.60 \%)$ become $80.80(92.40 \%)$ in cycle 2 . So, cycle 2 was bigger than cycle 1 $(92.40 \%>51.60 \%)$.

The last, Indah Permata Sari had done research by title "Improving Students' Reading Comprehension by Using PQ4R (Preview, Question, Read, Reflect, Recite, and Review) Strategy at Grade VIII SMP Negeri 5 Padangsidimpuan In academic year 2013/2014". She said that PQ4R improved students reading comprehension by using PQ4R. In this study, it had found that the improvement of students' achievement by using PQ4R Strategy. Cycle 1 was 68.12 (37\%) and Cycle 2 was 83.12 (95\%). So cycle 2 was bigger that cycle $1(95 \%>37 \%)$.

In this study, researcher also had found that the improvement of students' achievement through the title "Improving Students' Reading Comprehension by Survey, Question, Read, Write (SQRW) strategy at grade 
VIII SMP Negeri 1 Panyabungan. It was 53.69 (26.08\%) in first cycle, and it was $75.65(69.56 \%)$ in second cycle. So, the cycle 2 was bigger than cycle 1 $(69.56 \%>26.08 \%)$.

Based on the students' achievement in the above researches, researcher could be concluded that the third research had done by Yaspiah was higher than the first, second and the third research. It could be explained the improvement based on the classification quality of students' score in chapter III. The first research had done by Rizka Ummul Khaira was categorized as good which the SQRW to students' reading comprehension. The score is 62 . The second research had done by Arisan Jaya was categorized as very good, the percentage of cycle 1 and cycle 2 were $51.60 \%-92.40 \%$. The third researcher had done by Indah Permata Sari was categorized as very good, the percentage of cycle 1 and cycle 2 were $37 \%$ - 95 .

\section{Influence Factors}

After discussed about score in each research, the researcher continued the explanation about the problems in each research.

The first, Rizka Ummul Khaira found the problem in identifying character, students wrote without identified the characteristic of actor on the story and students did not know the meaning of the question. Arisan Jaya did not have problem in identifying character but found the problem in identifying main idea; students difficult to find main idea whether it was in the first or in the last paragraph. Indah Permata sari found the problem in identifying exclude fact; was caused by the factors that many statements were almost same and only had little different from the text, and did not have problem in identifying character. Furthermore, researcher found the problem in identifying topic sentence; difficult to identify the meaning of the word that refers to topic sentence and difficult to find the topic sentence whether it was in the first or last paragraph, and also did not have problem in identifying character.

The second, Rizka Ummul Khaira found the problem in identifying setting; students did not understand about setting was. Arisan Jaya, Indah Permata Sari, and also researcher did not have problem in identifying setting, and researcher found the problem in identifying meaning of difficult word; students difficult to identify unfamiliar vocabulary items and difficult to interpret the meaning of the word. 
The third, Rizka Ummul Khaira found the problem in identifying coda; they know the coda but did not know to translate into English. Arisan Jaya, Indah Permata Sari and researcher did not have problem in identifying coda. Furthermore, researcher found the problem in identifying important information; students difficult to make relationship between the text to their background knowledge and difficult to interpret what they have been read in order to identify important information.

The fourth, Rizka Ummul Khaira, Arisan Jaya, and Indah had same problem in identifying vocabulary in context; they did not know what the meaning from the word because they were lack of vocabulary until they had difficulty when identifying vocabulary in context. Furthermore, researcher had not found the problem in identifying vocabulary in context.

The fifth, Indah Permata Sari and researcher found the problem in identifying supporting sentence; students did not understand how supporting sentences was and they did not know where the lie of supporting sentences was. Furthermore, Rizka and Arisan Jaya did not have problem in identifying supporting sentence.

Based on the problems and solutions above, it can be concluded that the students' problem in reading comprehension could be solved by using some strategies, especially by using SQRW strategy. Moreover, Using P2R and $\mathrm{PQ} 4 \mathrm{R}$ was also proven that there was an improvement in students' reading comprehension achievement.

\section{CONCLUSION}

Based on the result of the research, researcher concluded that: SQRW strategy can improve students' reading comprehension at grade VIII SMP Negeri 1 Panyabungan. It based on the students' reading comprehension; the mean score in first cycle was $53.69(26.08 \%)$ and in second cycle 75.65 $(69.56 \%)$. There were four of external factors that influencing students' reading comprehension were; motivation, move to another chair, noisy, and asking permission. Therefore, the hypothesis in the research could be accepted. The learning, the value and the condition in reading comprehension by using survey, question, read, and write (SQRW) strategy has shown the good improvement in class VIII-2 SMP N 1 Panyabungan. 
310 | TAZKIR: Jurnal Penelitian Ilmu-ilmu Sosial dan Keislaman

Vol. 03 No. 2 Desember 2017

\section{REFERENCES}

Arisan Jaya. Improving Students' Reading Comprehension by Using P2R (Preview, Read, Review) Strategy at Grade VIII Pondok Pesantren Al-Mukhlisisn Sumu. A Thesis, STAIN Padagsidimpuan, 2013.

Brown, H. Douglas. Language Assessment Principles and Classroom Practices. United Stated of America: Longman, 2004.

Burns, Anne. Doing Action Research in English Language Teaching. New York: Routledge, 2010.

Harris, Albert J. How to Increase Reading Ability. New York: David Mckay Company, 1969.

Indah Permata Sari. Improving Students' Reading Comprehension by Using PQ4R (Preview, Question, Read, Reflect, Recite and Review) Strategy at Grade VIII SMP Negeri 5 Padangsidimpuan. A Thesis, STAIN Padangsidimpuan, 2014.

List book of students' value at SMP Negeri 1 Panyabungan, private Document, (SMP Negeri 1 Panyabungan 23 $3^{\text {th }}, 2014$ at 11:30 am).

Mills, Geoffrey E. Action Research a guide for the Teacher Researcher. New Jersey: Prentice Hall, 2000.

Nunan, David. Practical English Language Teaching. New York: Mc Grow Hill, 2003.

Orlich, Donald C. Teaching Strategies A Guide to Better Instruction. D. C. Heath and Company: Texington Massachusets Toronto.

Otto, Wayne. How to Teaching Reading. Philippines: Addison-Wesley Publishing Company, 1979.

Richards, Jack C. Methodology in Language Teaching. New York: Cambridge University Press, 2002.

Rizka Ummul Khaira. The Use of SQRW Strategy increasing students' ability in Narrative text at MA Darel Hikmah Pekanbaru. A Thesis, UNRI Pekanbaru, 2011.

Rochiati Wiratmadja, Metode Penelitian Tindakan Kelas. Bandung: Rosda, 2005.

Roebl, K. M. Developing Reading Comprehension Skills in EFL University Level Students. St. John's University: Taiwane, 2003.

S. Stephen, Strichart and Charles T. Mangrum, Teaching Learning Strategies-and Study Skills to Students with Learning Disabilities, Attention Deficit Disorders or Special Needs//. (Browsed at April 18, 2015. Time 14.00 p.m).

Smith, Nil B and H. Alan Robinson. Reading Instruction for Today's Children. Englewood Cliffs: 1980.

Suharsimi Arikunto, Menajemen Penelitian. Jakarta: PT. Rineka Cipta, 2003. 